\title{
How to bring a technical artifact into use: A micro- developmental perspective
}

Citation for published version (APA):

Overdijk, M., Van Diggelen, W., Andriessen, J., \& Kirschner, P. A. (2014). How to bring a technical artifact into use: A micro-developmental perspective. International Journal of Computer-Supported Collaborative Learning, 9(3), 283-303. https://doi.org/10.1007/s11412-014-9195-6

\section{DOI:}

$10.1007 / \mathrm{s} 11412-014-9195-6$

Document status and date:

Published: 01/09/2014

Document Version:

Peer reviewed version

Please check the document version of this publication:

- A submitted manuscript is the version of the article upon submission and before peer-review. There can be important differences between the submitted version and the official published version of record. People interested in the research are advised to contact the author for the final version of the publication, or visit the DOI to the publisher's website.

- The final author version and the galley proof are versions of the publication after peer review.

- The final published version features the final layout of the paper including the volume, issue and page numbers.

Link to publication

\section{General rights}

Copyright and moral rights for the publications made accessible in the public portal are retained by the authors and/or other copyright owners and it is a condition of accessing publications that users recognise and abide by the legal requirements associated with these rights.

- Users may download and print one copy of any publication from the public portal for the purpose of private study or research.

- You may not further distribute the material or use it for any profit-making activity or commercial gain

- You may freely distribute the URL identifying the publication in the public portal.

If the publication is distributed under the terms of Article 25fa of the Dutch Copyright Act, indicated by the "Taverne" license above, please follow below link for the End User Agreement:

https://www.ou.nl/taverne-agreement

Take down policy

If you believe that this document breaches copyright please contact us at:

pure-support@ou.nl

providing details and we will investigate your claim.

Downloaded from https://research.ou.nl/ on date: 26 Apr. 2023 


\title{
How to bring a technical artifact into use: A micro-developmental perspective
}

\author{
Maarten Overdijk • Wouter van Diggelen • \\ Jerry Andriessen • Paul A. Kirschner
}

Received: 21 March 2013 / Accepted: 6 June 2014

(C) International Society of the Learning Sciences, Inc. 2014

\begin{abstract}
In order to understand how technical artifacts are attuned to, interacted with, and shaped in various and varied classrooms, it is necessary to construct detailed accounts of the use of particular artifacts in particular classrooms. This paper presents a descriptive account of how a shared workspace was brought into use by a student pair in a face-to-face planning task. A micro-developmental perspective was adopted to describe how the pair established a purposeful connection with this unfamiliar artifact over a relatively short time frame. This appropriation was examined against the background of their regular planning practice. We describe how situational resources present in the classroom - norms, practices and artifactsframe possible action, and how these possibilities are enacted by the pair. Analysis shows that the association of norms and practices with the technical artifact lead to a contradiction that surfaced as resistance experienced from the artifact. This resistance played an important part in the appropriation process of the pair. It signaled tension in the activity, triggered reflection on the interaction with the artifact, and had a coordinative function. The absence of resistance was equally important. It allowed the pair to transpose or depart from regular procedure without reflection.
\end{abstract}

Keywords Appropriation - Enactment $\cdot$ Resistance $\cdot$ Plan construction $\cdot$ Shared workspace

M. Overdijk

Department of Educational Sciences, Utrecht University, Utrecht, The Netherlands

W. van Diggelen

Department of Education, Da Vinci College, Dordrecht, The Netherlands

J. Andriessen

Wise and Munro Learning Research, The Hague, The Netherlands

P. A. Kirschner

Centre for Learning Sciences and Technologies (CELSTEC), Open University, Heerlen, The Netherlands

M. Overdijk ( $\square)$

Nieuwstraat 47, 2312 KA Leiden, The Netherlands

e-mail: maartenoverdijk@hotmail.com 